\title{
The governance of the Court of Arbitration for Sport
}

\author{
Jean-Loup Chappelet
}

\section{Introduction}

The idea for setting up a Court of Arbitration for Sport (CAS) was first put forward in the early 1980 s by Keba Mbaye, then the IOC member for Senegal and a judge at the International Court of Justice at The Hague (the UN's main judicial organ). Mbaye's proposal was made in response to International Olympic Committee (IOC) President Juan Antonio Samaranch's desire to create a way of settling sporting disputes that would be quicker and cheaper than going through national civil courts. As well as being considered slow, expensive, and unfamiliar with the particularities of sport, the transnational nature of sport meant that national courts were often inappropriate places for resolving sporting disputes as parties would typically belong to different jurisdictions. Mbaye's solution was to set up a system of arbitration, an internationally recognized technique that was already being used in other transnational domains, most notably international trade, to adjudicate disputes between parties belonging to different jurisdictions. Acting on Mbaye's proposal, the IOC agreed on the statutes for CAS in 1983, allowing the court to begin operations in 1984 with Mbaye as its first president. In fact, the creation of CAS could not have been more timely for the Olympic and Sports movement, which was becoming alarmed by the increasing tendency for dissatisfied parties (particularly athletes) to challenge the legality of its rules and decisions. For example, the years preceding the creation of the CAS had seen rulings by two sport federations (football, Dona-Mantero case in 1976; cycling, Walrave and Koch case in 1974) overturned by the European Court of Justice (formerly the Court of Justice of the European Communities and now known as the Court of Justice of the European Union) and a Taiwanese IOC member had filed a lawsuit against the IOC in a Lausanne court (location of the IOC's headquarters) in 1979.

In the three-and-a-half decades since its foundation, the CAS has become a key institution for ensuring the integrity and regulation of the world's sport organizations and the Olympic movement (Chappelet, 2016, p. 54). It has been recognized as a true arbitration tribunal by the supreme courts of both Switzerland and Germany (see later), and has been designated the highest body of appeal by most international sport federations (IFs), including the IFs for all Olympic and many aspiring Olympic sports, the IOC, the International Paralympic Committee (IPC), the World Anti-Doping Agency (WADA, since 2003), the Fédération Internationale 
Jean-Loup Chappelet

de Football Association (FIFA, since 2002), the International Association of Athletics Federations (IAAF, since 2001), and the Union of European Football Associations (UEFA). Most importantly, it has created a body of jurisprudence for sports disputes and contributed to the harmonization and evolution of sport organizations' sporting rules so they comply with basic principles of justice, such as the right to be heard and the proportionality of punishment. This has led to the formation of what is generally known as the lex sportiva, a compendium of transnational sporting rules for IFs and arbitrational jurisprudence arising from decisions (known as 'awards') made by the CAS over the years. Many sports disputes end up in front of the CAS, whose decisions are generally accepted as final by the parties involved, especially in cases concerning the integrity of sports administrators (e.g. the CAS reduced from six years to four years the suspension imposed on UEFA's former president, Michel Platini, in the wake of the "FIFA scandal" in 2015-2016).

Despite being rooted in the Olympic and world sport system, the CAS and the way it operates have not always been. well understood. In order to help remedy this situation, this chapter provides an overview of the CAS's governance and suggests possible ways of improving it. The concept of governance was constructed in the 1990 s by scholars investigating the operating modes that sectors combining public and private actions were adopting in order to avoid intrusive regulation by public entities, the state, or the courts (e.g. Kooiman, 1993; Leftwich, 1994; Rhodes, 1996) - what Rosenau and Czempiel (1992) referred to as "Governance without government".

This chapter is structured as follows. First, we describe a practical, hierarchical nodel of governance that goes beyond the internal day-to-day management of organizations. Systematically applying this model to the CAS provides a clear overvicw of the court governance (which is done in the third section) and reveals a number of issues that could be explored in order to improve this governance. The fourth section describes these issues, which are put forward for discussion within the CAS and beyond. The conclusion highlights the importance of continually improving the CAS's governance and thereby ensuring the continued legitimacy of "sports justice" in the eyes of all its stakeholders.

\section{A practical model of governance}

In a famous paper published in 1996, Rhodes argued that the word governance had too many meanings (he listed six) to be useful. Nevertheless, the term, if not all its possible meanings, has flourished to such an extent that it is now part of the everyday lexicon. Governance first became an important issue in the world of sport in 1999, when the so-called Salt Lake City scandal (Wenn, Barney and Martyn, 2011) forced the IOC to reform its structure and introduce major changes to the Olympic Charter. These reforms included measures to improve the organization's governance, such as setting an age limit for IOC members (70 years old), restricting presidential terms of office to a maximum of 12 years, introducing a Code of Ethics to be overseen by an Ethics Commission, and setting up a nominations commission (now known as the Members Election Commission). In 2009 the IOC adopted its "Basic Universal Principles of Good Governance of the Olympic and Sports Movenent" (IOC, 2008), generally referred to as the BUPs, and used its Code of Ethics to make them obligatory within the Olympic movement. In 2015, following scandals within the IFs for football (FIFA) and athletics (IAAF), the IOC issued a declaration on "good governance in sport and the protection of clcan athletes". It also welcomed the decision by the Association of Summer Olympic International Federations (ASOIF) to set up a working group on the governance of sport in order to evaluate the governance of its members and help them improve it (IOC, 2015). 
The governance of the CAS

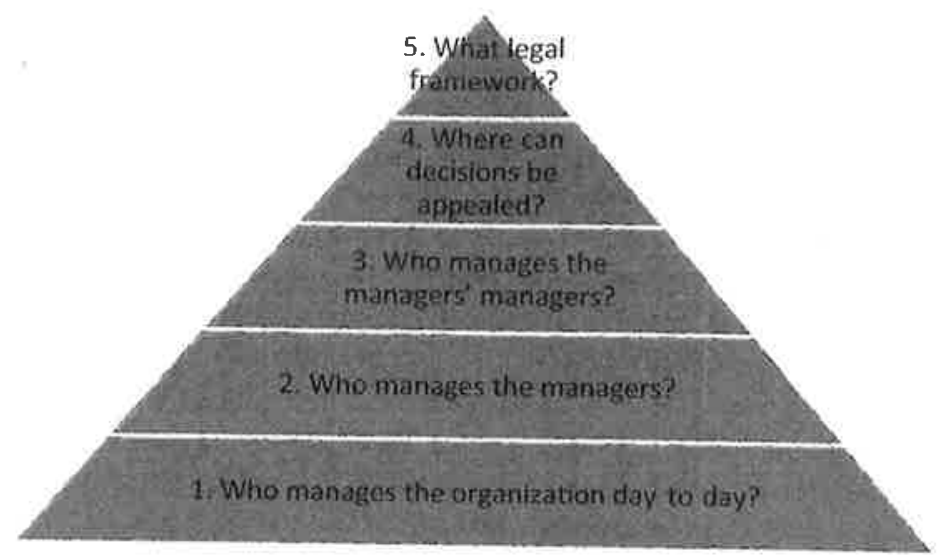

Figure 27.1 The five questions associated with Pérez's five levels of governance

Source: Author adapted from Pérez (2003)

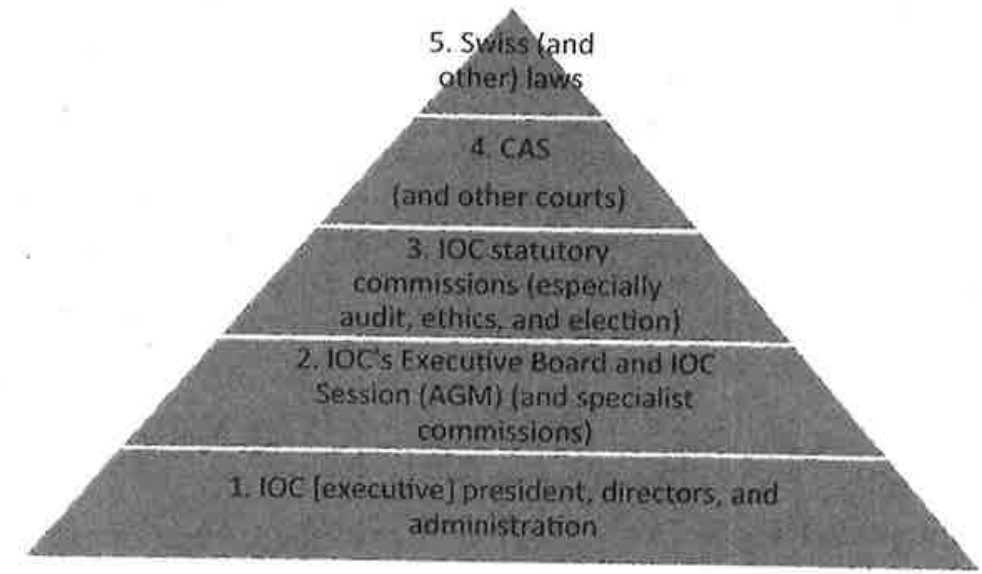

Figure 27.2 Pérez's model applied to the IOC

Source: Author

Beyond Rhodes's and other authors' theoretical approaches, a practical approach to analyzing governance is provided by Pérez's hierarchical model, which divides governance into five levels, from day-to-day management to the legal framework within which an organization operates (Pérez, 2003). Although this model was conceived in rélation to the corporate world, it provides an excellent template for examining the structural governance of sport and its organizations. Pérez drew up his model to answer five fundamental questions about an organization's operating mode and structures (Figure 27.1).

Figure 27.2 shows the answers to these questions in relation to the IOC, following the reforms introduced in 1999 in the wake of the Salt Lake City scandal (for more details, see Chappelet, 2012). Under the Olympic Charter (rule 61), appeals against decisions made by the 
Jean-Loup Chappelet

IOC and its Executive Board can be taken to the CAS, but only in "certain cases" (not specified). However, the IOC explicitly designates the CAS as the sole body of appeal in the case of disputes between the IOC and an Olympic host city or its National Olympic Committee (NOC) (article 51.2 HCC, 2016). What is more, Olympic Games entry forms and the byelaws to rule 44 of the Olympic Charter stipulate that athletes and officials participating in the Olynupic Games must submit "Olympic disputes" to the CAS. All the IFs that recognize the CAS have included a similar obligation for their competitions, notably in the case of disciplinary sanctions. Nevertheless, the CAS has overturned or modified numerous decisions made by sport's governing bodies. For example, the CAS found against the IOC in a case brought by Canadian snowboarder Ross Rebagliati in 1998, and it suspended the IAAF's rules on hyperandrogenism (athletes recognized as female but who have naturally high testosterone levels) following the Dutee Chand case in 2015, an issue not yet resolved in 2020. Another example is the CAS 2018 award cancelling the IOC's doping bans on 28 Russian athletes while upholding the bans against 11 other Russian athletes a few days before the start of the PyeongChang Olympic Winter Games 2018 (PerezPeña and Panja, 2018).

In the case of the IOC, levels 1 to 3 of Pérez's model are comprised almzost entirely of structures and rules put in place by the IOC itself through its statutes, whereas levels 4 and 5 involve external structures and require state intervention in the form of national and sometimes international laws. The IOC, like many other international sport organizations, most of which are associations set up under articles 60-79 of the Swiss Civil Code, is subject to Swiss law. In contrast, the CAS was set up as an arbitration tribunal under chapter 12 of Switzerland's Federal Act on Private International Law (LDIP in the. French acronym: Loi fédétale sur le droit international

Private pubtie). Olympic sport organizations welcome such cooperation with governments (and their laws) and accept the need to practice "good govemance" (see, for example, point 7 of the BUPs) in exchange for maintaining their autononny: they call this attitude "responsible autonomy" or, in other words, a sport organization deserves autonomy if it does "good governance".

International law applicable to sport is still in its infancy. To date, it covers just four areas, each of which is the subject of an international treaty:

- Spectator violence and misbehavior (Council of Europe, 1985, 2016);

- Corruption (not only in sport) (UN, 2003);

- Doping in Sport (UNESCO, 2005);

- Manipulation of sports competitions (Council of Europe, 2014).

The Council of Europe's 2014 Convention on the Manipulation of Sports Competitions and 2016 Convention on an Integrated Safety, Security and Service Approach at Football Matches and Other Sports Events, which builds on the 1985 Convention on Spectator Violence and Misbehavior, have now (in 2020) been ratified. The 2005 UNESCO Convention on Doping in Sport and the 2003 UN Convention. Against Corruption have also been ratified by many countries and therefore incorporated into their national legislation. Countries which ratify the Convention Against Corruption (public and private, passive or active) are required to criminalize corrupt practices, such as bribery, influence peddling, fraud, and money laundering, if these practices are not already criminal offenses under existing national laws. Other conventions against corruption, such as those drawn up by the Council of Europe and the Organization for Economic Cooperation and Development (OECD), may also apply to sport cases.

Moreover, judicial authorities are increasingly using national laws to sanction misconduct in sport. As noted previously, many sport organizations are subject to Swiss law, with the result that some have felt the attentions of Switzerland's civil and criminal prosecutors (FIFA affairs, 
see Chappelet, 2010). However, such actions are not restricted to Switzerland. For example, in 2016 France's Financial Prosecutor's Office opened an inquiry into a former IAAF President, and Brazilian prosecutors carried out investigations into allegations of ticket-touting by an IOC member and corruption by the president and director general of the Rio 2006 organizing committee (who all deny the accusations). Some countries, notably Germany, Austria, France, Italy, and Kenya, have made doping by athletes a criminal offense (trafficking in performanceenhancing drugs is a criminal offense in most countries).

However, the most notable development has been the United States justice system's increased willingness to police international sport. High-profile examples of this include the US Attorney General asking the Swiss authorities in 2016 to arrest 12 FIFA members of its executice committee for extradition to the United States, and an investigation by a New York district prosecutor into doping at the 2014 Winter Olympics in Sochi, Russia. Such actions are made possible by US laws such as the Racketeer Influenced and Corrupt Organization (RICO) Act and the Foreign Corrupt Practices Act (FCPA), which extend US jurisdiction beyond the United States' geographical borders (Henning, 2016; Lipschutz, 2009). The Rodchenkov Act discussed in the US Congress in 2020 would criminalize doping and give American prosecutors unprecedented authority over global sport.

\section{Pérez's model applied to the CAS}

Applying Pérez's model to the CAS (see Figure 27.3) provides a systematic overview of how the tribunal functions (by level); it identifies its weak points and highlights the role of the International Council of Arbitration for Sport (ICAS). It helps us understand how the CAS complex regime, mixing public and private law, functions.

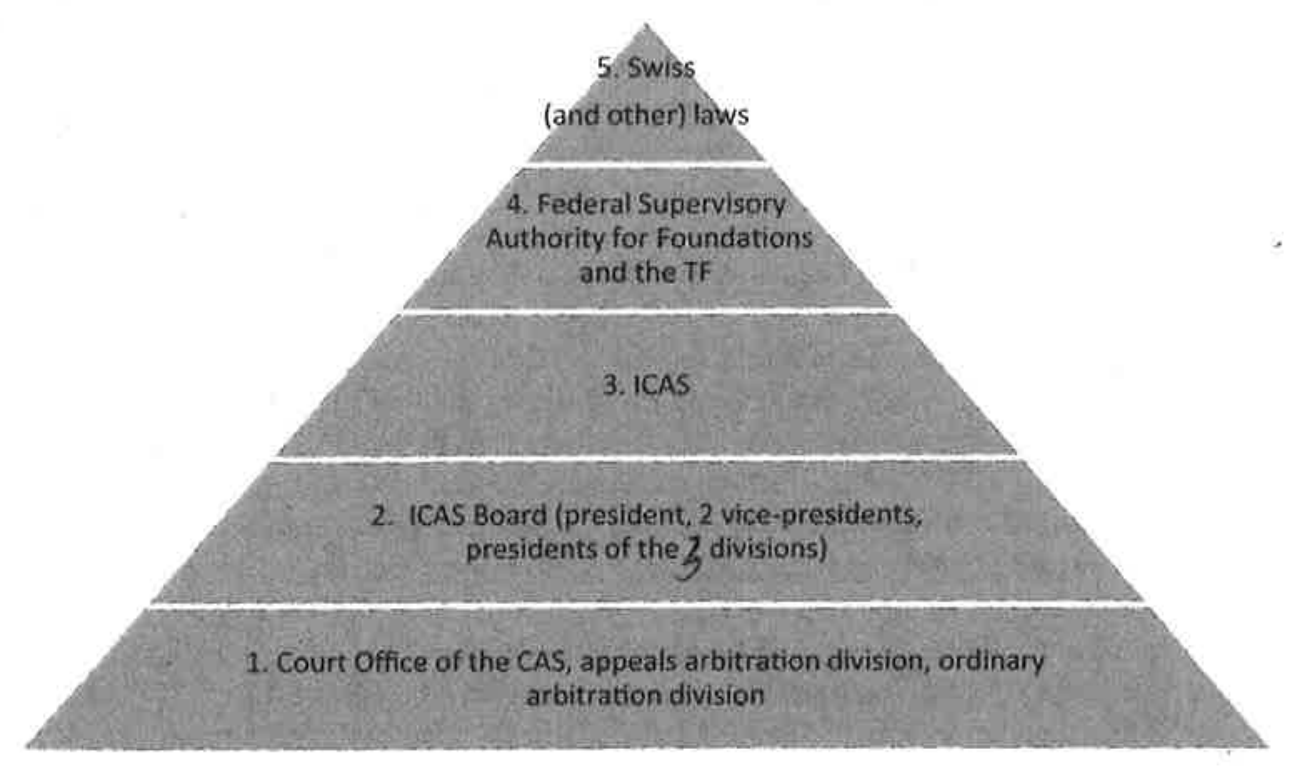

Figure 27.3 The five levels of governance within the CAS

Source: Author 
Jean-Loup Chappelet

The analysis of each level will provide us with suggestions (in the next section) on how to improve CAS or further develop its structure and organization.

Pérez's first level (Who manages the organization day-to-day?) is composed of the CAS's Court Office, which, following a current trend in justice-system management research, can be considered the CAS's 'management' (Lienhard, Kettinger and Emery, 2016). It consists of a permanent secretary general, a deputy secretary general, a financial director, 11 councilors (all legal experts), and secretaries. The councilors can be considered 'managers' because they are responsible for the day-to-day organization of the numerous procedures subunitted to the CAS. They are supervised by the secretary general, who is a sort of chief executive officer (CEO). In addition, the CAS has three divisions to which the different types of dispute it is asked to arbitrate are assigned. As its name suggests, the Appeals Arbitration Division deals with appeals against disciplinary sanctions handed down by sport organizations (once the organization's internal appeals procedures have been exhausted). The Ordinary Arbitration Division hears all the other cases accepted by the CAS, except doping disputes. An Anti-Doping Division was added in 2019.

Neither division has permanent, salaried arbitrators. Instead, they call upon arbitrators from pre-established lists (see later discussion), as and when required. These arbitrators receive a fee of CHF300 to 500 (in 2020) for each hour they work. There are four types of dispute-resolution procedure: appeal, ordinary, mediation, and ad hoc. (Ad hoc divisions are set up on site during major events, such as the Olymnic Games, so any disputes that arise can be resolved quickly. A separate ad hoc division to adjudicate cases of doping was set up for the first time at the 2016 Rio Olympics.) Disputes brought before the CAS are processed according to a set of Procedural Rules. Mediation cases are governed by a separate set of rules. The CAS registered almost 600 procedures in 2016, and has processed more than 5,000 procedures since its foundation (CAS, 2017). Most procedures are appeals (458 appeals procedures in 2016) and are related to cases of doping. This is likely to continue given the IOC's desire to make the CAS the primary adjudicator in all doping cases (through new Anti-Doping Division which started operations in 2019). The CAS's non-binding mediation service is rarely used, undoubtedly because it is not obligatory to furst go through a mediation process (in contrast to the arbitration procedure introduced by France's NOC, in which cases must first go to mediation). Ordinary procedures, of which there were 100 in 2016, concern contractual and commercial relationships. The ad hoc divisions at the 2016 Rio Olympics heard 41 cases (CAS, 2017). More recent statistics are not publicly available.

As well as its headquarters in Lausanne, the CAS has decentralized offices in New York and Sydney, and alternative hearing centres in Abu Dhabi, Kuala Lumpur, Cairo, and Shanghai. As noted, temporary offices, including a specific division for processing doping cases (since Rio 2016), are set up for major competitions, most notably the Olympic Games (since Atlanta 1996). The CAS's website provides a schedule of arbitration costs, which consist of a fixed Court Office fee (currently CHF1,000), an administration fee that varies according to the size of the disputed sum (from CHF100 to CHF25,000), and the arbitrators' costs and fees. Under certain circunstances, and on request from the parties, the ICAS may provide financial aid to cover part of the parties' costs.

'The second level of Pérez's model (Who manages the managers?) consists of the ICAS Board, whereas the third level (Who manages the managers' managers?) consists of the full ICAS (International Council of Arbitration for Sport). The ICAS was founded in Paris as a Swiss foundation in 1994, the IOC's centenary year, by the IOC, the Association of National Olympic Committees (ANOC), and the umbrella associations for the IFs of Summer and Winter Olympic sports (ASOIF and AIOWF). Together, these organizations provide about two-thirds of the ICAS's 
(and, therefore, of the CAS's) funding. In 2016, the IOC, ANOC, and ASOIF/AIOWF each provided $21 \%$ of the ICAS/CAS's funding (Sternheimer, 2016); however, it should be remembered that the ANOC, ASOIF, and AIOWF are mostly funded by the IOC. The ICAS obtains the remaining third of its budget from the fees paid by the parties whose cases are heard by the CAS.

The ICAS was created in 1994, in response to remarks about the CAS's independence by Switzerland's supreme court, the Tribunal Fédéral, in its judgment on a case brought before it by horse rider Elmar Gundel. Gundel had challenged CAS's decision concerning his appeal against a doping sanction imposed by the International Equestrian Federation (FEI), claiming that the CAS was not independent from sport's governing bodies. Although the Tribunal Fédéral rejected Gundel's appeal, ruling that the CAS was independent from the FEI, the judges noted that the IOC's close links with the CAS might have prevented them reaching a fair decision if the case had involved the IOC directly (Tribunal Fédéral 1993). In fact, at that time the IOC not only financed the CAS, it also provided its prenuises and appointed its arbitrators. The Tribunal Fédéral's remark led the CAS's founders to create the ICAS, approving its statutes in what became known as the "Paris Agreement". These statutes, which also cover the CAS, are known as the "Code of Sports-Related Arbitration" and have been updated regularly since they first came into force, in 1994. A set of Procedural Rules, approved by the ICAS, supplements the Code.

The ICAS Board is a subset of the ICAS, consisting of five of its 20 menbers: ICAS's president and two vice-presidents, plus the president of the Ordinary Arbitration Division, and the president of the Appeals Arbitration Division. The CAS's secretary general is also the Board's secretary, but is not a voting member of the Board. ICAS's president, who is also the president of the CAS, oversees the application of the Code. The CAS provides the infrastructure needed to resolve, by arbitration, the sporting disputes submitted to it. Hence, the president fulfills the role of chairman (of the board), distinct from the CEO (secretary general), quite rightly from a governance point of view.

All 20 members of the ICAS are appointed for renewable periods of four years as follows: the IOC appoints four members, the Olympic IFs appoint four members (three for the ASOIF and one for the AIOWF), the ANOC appoints four members; these first 12 members appoint a further four members, as a way of "safeguarding the interests of the athletes" (article S4 of the Code), and the first 16 members appoint the remaining four members from annong personalities independent of the IOC, ANOC, ASOIF, and AIOWF.

The ICAS has numerous attributions (article $\$ 6$ of the Code), but many of these attributions can be (and often are) delegated to the Board. Attributions that cannot be delegated include revising the Code (any revisions to the Code must be approved by at least two-thirds of the ICAS's members), electing ICAS's president and vice-presidents, and the presidents of the CAS's divisions, and approving the CAS's budget and accounts, which are prepared by the Court Office and submitted to the Board. The ICAS meets at least once a year.

One of the ICAS's main responsibilities is to appoint general or football-specific arbitrators and mediators. Potential arbitrators are nominated by the Board and are appointed for terms of four years, renewable without limit. The ICAS can also remove arbitrators from the CAS's lists. In 2020, the CAS's lists (published on its website) included 393 general arbitrators from more than 95 countries, 104 football arbitrators, and 58 mediators. For each procedure, three arbitrators are chosen from these lists by the parties involved: one party chooses the first arbitrator, the other party chooses a second arbitrator, and the first two arbitrators choose the president of the panel by mutual agreement. If mutual agreement is not reached within a set time limit, the president of the relevant division appoints the president of the panel. The 
Jean-Loup Chappelet

president of the panel can be recused by the ICAS or must recuse himself/herself if legitimate doubts could be raised about his/her independence (article S21 of the Code). The choice of arbirtrators by the parties is crucial. Following their appointment, arbitrators and mediators must sign a declaration of impartiality and independence. As a further measure to avoid accusations of conflicts of interest, a new rule added to the Code excludes any person who is acting as counsel for a party before the CAS from serving as an arbitrator (article S18 of the Code). Similarly, members of the ICAS cannot be arbitrators (article S5). On the other hand, some arbitrators are selected much more frequently than others and therefore have much more information than other arbitrators or potential parties. A system of financial aid and pro bono legal advice has been recently introduced. The appeals procedure is free, with the exception of a set fee of CHF1,000; however, the parties often incur substantial legal costs. (WADA complained that the appeal by the cyclist Floyd Landis in 2007-2008 cost it more than $€ 840,000$.) Sometimes, upon its division president, the CAS appoints a one-member only panel (instead of three).

The 1994 Paris Agreement (Reeb, 2004, p. 680 and subsequent) created the ICAS as a foundation established under Swiss law (articles 80-89a of the Swiss Civil Code). All important foundations registered in Switzerland are monitored by the Federal Supervisory Authority for Foundations, a public body within the Federal Department (ninistry) of Home Affairs, which checks that a foundation's assets are used for their declared purpose and that any modifications to its statutes (here the Code) comply with Swiss law. Hence, the Federal Supervisory Authority, together with the Tribunal Fédéral, constitutes the fourth level in Pérez's model (Where can decisions be appealed?). This legal arrangement is subject to the Federal Act on International Private Law (LDIP), which governs arbitration in Switzerland. More specifically, cases heard by the CAS are subject to "Chapter 12 International Arbitration" (articles 176 to 194) of the LDIP, unless both parties are donziciled in Switzerland (such cases fall within the jurisdiction of Switzerland's civil courts). The CAS's awards can be appealed to the Tribunal Fédéral, but only in certain circumstances set down in the LDIP, most notably irregtlarities in the designation of the arbitration panel, failure to respect procedures, or an award that is "incompatible with Swiss public policy". The CAS's decisions are applicable in every country that has ratified the 1958 New York Convention on the Recognition and Enforcenent of Foreign Arbitral Awards (over 125 countries in 2017, with the exception of certain African countries) and every sport/ IF which has recognized CAS in its statutes.

Some of the CAS's awards have been appealed to the Tribunal Fédéral by one of the parties. The Gundel case led to the creation of the ICAS and major reforms to the CAS's statutes. In 2010, German speed skater Claudia Pechstein filed an appeal with the Tribunal Fédéral in which she contested the CAS's independence from the concerned IF. The Tribunal Féderal rejected her appeal, and she took her case to the German courts over abuse of dominant position by the IF, where her arguments were eventually rejected by Germany's Federal court despite an initial ruling in her favor by a Bavarian court. If Germany's highest civil court had found in Pechstein's favor, this decision would have called into question the entire edifice patiently constructed by the CAS and the ICAS. A further appeal by the athlete to the European Court of Hunzan Rights in Strasbourg was dimissed in 2019 but recommends public hearings. In 2019, another appeal to the German Constitutional Count is pending (Reinholz, 2019).

Level 5 of Pérez's model (What legal frameworks?) comprises all Swiss legislation relating to what Pérez calls 'metagovernance', including the previously mentioned 1987 Federal Act on Private International Law (LDIP) and some international legislation such as the 1958 New York Convention (ratified by Switzerland). However, the parties in a dispute may, by common accord, choose to have their case heard under a law other than Swiss law, which is the default 
law for CAS arbitration procedures. Similarly, the parties may agree to the case being heard in a language other than one of the CAS's two default languages, English and French. Furthermore, if there is no contractual clause obliging the parties to accept arbitration by the CAS, they may submit their dispute to the civil courts in their country of residence or to any other arbitrational authority (including the CAS by later agreement). However, all international sport federations currently oblige their athletes to accept arbitration by CAS when they sign their entry form for a competition.

In 2019, the LDIP has been revised in order to maintain Switzerland as a major, attractive centre for arbitration. Several countries, including Germany, Canada, France, New Zealand, and the United Kingdom, have national courts of arbitration for sport that are not affiliated to the CAS. (The CAS can also accept cases in which both parties are Swiss if they are not resident of the same canton.) The obligation for athletes to subnit disputes to the CAS, imposed by many IFs and sports competitions, has been judged to be legally acceptable and not to be an abuse of their dominant position in the market (judgment in the Pechstein case).

All criminal cases are heard in the relevant national courts (as CAS only deals with civil cases). For example, FIFA's former president Sepp Blatter will face crinunal proceedings in Switzerland over allegations of mismanagement and misappropriation of funds (articles 138 and 158 of Switzerland's criminal code). Revelations of corruption within FIFA had already led to Blatter being banned by FIFA from all footballing activities for eight years, later reduced to six years (sporting sanction). Blatter's appeal to the CAS was rejected but he decided not to take his case to the Tribunal Fédéral.

\section{Issues to explore in order to improve the CAS governance}

A striking feature of the first level of governance is the small size of the CAS's day-to-day management team, as the Court Office employs just 15 people, plus secretaries, to deal with more than 600 procedures a year (in 2016). Of course, arbitrators, once appointed, run their procedures themselves, but the Court Office still has to supervise these procedures (most of which take around six to 12 months), organize hearings (which are held in Lausanne, unless the parties agree otherwise), slightly copyedit and publish certain awards, etc. Nevertheless, the Court Office has increased in size over the years, as when the CAS was founded it had just one, part-time, secretary general. The Court Office currently occupies an entire mansion in Lausanne (known as the "Château de Béthusy"), but it is due to move into larger premises in the Palais de Beaulieu (Lausanne's conference centre). Because the Court Office constitutes the entire first level of Pérez's model (2003), its modest size could affect CAS's award delays and quality as the Court Office is clearly overburdened. Statistics on how long procedures take are needed in order to determine to what extent this is the case,

The biggest hurdle to expanding the Court Office would probably be cost, but data on the CAS's finances is difficult to obtain because the CAS does not publish an annual report, which is clearly not a good example of transparency: a basic feature of organizational governance. According to the IOC Annual Report of 2015, the IOC allocated US $\$ 7,931,000$ to the ICAS/ CAS in 2015 and US $\$ 8,275,000$ in 2014 (IOC, 2015, p. 170). Given that this sum is supposed to cover $21 \%$ of the CAS's budget (Sternheimer, 2016), its total budget for 2016 can be estimated to have been approximately US $\$ 38$ million. All the CAS's awards since 1986 , except confidential awards (mostly arising from ordinary procedures), have been added to a database consultable via the CAS website. Publishing these awards has greatly increased the coutt's transparency, which is one of the pillars of organizational governance (see, for example, the fourth pillar of the BUPs - Basic Universal Principles of Good Governance in the Olympic and Sport Movement). 
Jean-Loup Chappelet

The CAS also publishes useful commentaries on cases and digests of awards (see, for example, Mavromati and Reeb, 2015).

ICAS's five-member Board plays a fundamental role at level 2 because its five members draw up draft decisions, which are then presented to the full ICAS for approval (level 3). The president of the Appeals Arbitration Division has a particularly heavy workload, as this division processes many of the CAS's procedures (this nuight change with the new Anti-Doping Division). It is the division president who chooses the president of each arbitration panel (under article R.54 of the Procedural Rules, each of the parties chooses one of the other arbitrators from the CAS's list of arbitrators). Consequently, the division president can influence decisions through his/her choice of arbitrators. In 2020, the president of the Appeals Arbitration Division is Mrs. Corinne Schmidhauser, an attorney and former ski racer, and the president of Antidoping Switzerland, who took over from Thomas Bach in 2013, when he was elected president of the IOC. None of the ICAS's members, including the members of the Board, receive a salary from the CAS, but they probably receive some sort of remuneration and, of course, the CAS covers their expenses. The CAS's remuneration policy is not made public, which questions its transparency and accountability.

Level 3 consists of the 20 members of the ICAS, nine of whom are women in 2020 (a rare example of near gender parity). Two nuembers of the ICAS are also members of the IOC, including its current president, Mr. John Coates from Australia, who was a vice-president of the IOC (2013-2017). Although ICAS membership has been recently reviewed, its members are still often closely associated with organizations within the Olympic novement, and we do not know which founding organization proposed each ICAS member. In addition to approving any modifications to the Code (two-thirds majority required), the ICAS's main roles are to appoint the CAS's arbitrators, the members of its Board, and its secretary general. The ICAS can also recuse arbitrators when required. All appointments are for four years, which is short compared with the usual rules about the inmovability of judges. However, in contrast to many other sport organizations, including the IOC, there are no limits on how often terms can be renewed or on the age of appointees. Also unlike the IOC and FIFA, the CAS does not have an ethics commission or rules about conflicts of interest which are now conmon in many spott-related organizations.

Although the biographies of arbitrators on the CAS's website are very succinct, it can be seen that most arbitrators have close links with the world of sport, especially the IFs and NOCs. In fact, until 2010 these organizations nominated all the CAS's arbitrators. Of course, it is natural, if not essential, for the CAS's arbitrators to be familiar with the specificities of sport. However, the way in which arbitrators are appointed frequently raises questions about their independence from sport organizations (Vaitiekunas, 2014; Duval, 2015), even though this independence has been recognized by the suprene courts of both Switzerland and Germany (Gundel, Lazutina, and Pechstein cases). The ICAS can take steps to minimize this type of criticism by recusing an arbitrator from a procedure (or even removing him/her from the CAS list) if that arbitrator's independence is questioned, for example, by one of the parties in a dispute. Another issue relating to the choice of arbitrators is that many athletes feel they are underrepresented among the arbitrators. However, it is difficult to conceive of a system that would allow athletes to nominate arbitrators with a thorough knowledge of both sport and (sports) law. Organized representation for athletes through 'unions' such as UNI World Athletes, EU Athletes, and FIFPRO, unany of which are mono-sport, is yet to receive widespread recognition, especially from sport organizations. The CAS recently began taking steps to increase the number of athletes and women on its lists of arbitrators by organizing free training seminats for, for example, former athletes with legal training. 
More generally, greater representation for stakeholders (athletes, sponsors, broadcasters, sports event organizers, governments, etc.) other than traditional sport organizations could help improve the CAS's governance. It would be useful to have more detailed information about the arbitrators available, especially a list of the cases each arbitrator has adjudicated (in order to assess their experience). In fact, many arbitrators never sit on an arbitration panel and are listed merely to demonstrate the CAS's geographical diversity.

Under certain circumstances described in the LDIP, appeals against decisions made by the CAS can be submitted to Switzerland's supreme court, the Tribunal Fédéral (Pérez's level 4). As the guarantor of the country's legal system, it is funded by Swiss tax payers. It is based in Lausanne, which facilitates exchanges with the CAS if necessary. All the Tribunal Fédéral's rulings, including appeals concerning the CAS, are published (www.bger.ch/fr/jurisdiction-recht). A private website run by lawyers provides English translations of opinions issued by the Tribunal Fédéral in the field of international arbitration (www.swissarbitrationdecisions.com). Although the Tribunal Fédéral rejects the vast majority (93\%) of appeals against CAS awards (Sternheimer, 2016), it has canceled several awards for a procedural reasons (see Mavromati and Reeb, 2015 pp, 562-600). The most recent award canceled by the Tribunal Fédéral because it was "contrary to public policy" followed an appeal by a Brazilian professional footballer called Matuzalem who had been banned from playing/working for a Spanish club because he was unable/unwilling to pay his former employer the $€ 12$ million in compensation set by FIFA (Tribunal Fédéral, 2012). Matuzalem had taken his case to the Tribunal Féderal after his initial appeal to the CAS had been rejected.

The legal framework governing the CAS's operations is set by Swiss law (level 5 of Pérez's model). Some parties (mostly athletes) have filed appeals with state jurisdictions (German courts, European Court of Human Rights, Court of Justice of the European Union), following unsuccessful arbitration procedures. In addition, some countries have set up national courts of arbitration for sport (Germany, Canada, France, New Zealand, and United Kingdom), thereby creating the risk that the jurisprudence emanating from these courts will differ from the jurisprudence produced by the CAS. Such an eventuality would imperil the harmonization of the jurisprudence developed by the CAS over the years.

\section{Conclusion}

This chapter provides a brief overview of the CAS's governance and suggests a number of ways of improving it, taking into account the main precepts of modern governance, especially transparency, independence, and the representation of stakeholders. Stakeholder representation, in terms of the choice of arbitrators, is an especially important issue for the CAS.

Given the current spotlight on organizational governance - the period 2000-2013 saw the publication of more than 30 sets of principles of good governance in sport (Chappelet and Mrkonjic, 2013) - the CAS must ensure its governance is irreproachable and set its sights on achieving ever better governance, rather than just "good governance". Addressing the issues set out in this chapter as soon as possible would help the CAS achieve this and thereby maintain its legitimacy in the eyes of all its stakeholders.

\section{References} CAS. (2017). Statistiques - Statistics. Available at: www.tas-cas.org/fileadmin/user_upload/CAS_statistics_2016_.
pdf.

Chappelet, J-L. (2010). L'autonornie du sport en Europe. Strasbuurg: Council of Europe. 


\section{Jean-Loup Chappelet}

Chappelet, J-L. (2012). From daily management to high politics: The governance of the International Olympic Committee. In: L. Robinson et al., eds., The handbook of international sport management. London Routledge, pp. 7-25.

Chappelet, J-L. (2016). Jeux Olympiques: raviver la flanne. Lausanne: PPUR, chapter 3

Chappelet, J-L. and Mrkonjic, M. (2013). The basic indicators for better governance in international sport (BIBGIS). Lausanne: IDHEAP Working Papers.

Council of Europe. (1985). European convention on spectator violence and misbehaviout at sports events and in particular at football matches, Aug. Strasbourg: Council of Europe.

Council of Europe. (2014). Convention on the manipulation of sports competitions, Sept. Macolin: Council of Europe.

Council of Europe. (2016). European convention on integrated safety, security and service approach at football matches and other sports events, 218, July. Saint-Denis, France: Council of Europe

Duval, A. (2015). The court of arbitration for sport after Pechstein: Reform or vevolution? Asser International Sports Law Blog.

Federal Couxt. (1993). Judgment of the Federal Court of 15 Mas. Official Collection of Federal Court Judgments, 119 II 271.

HCC. (2016). Host city contract, principles, games of the XXXIII Olympiad-Candidature process 2024.

Henning, P.J. (2016). Road map for pursuit of soccer charges. International New York Times, p. 14.

IOC. (2008). Basic unituersal principles of good governance of the Olympic and sports movement. Lausanne: IOC.

IOC. (2015). OC Executine Board adopts declaration on good governance in sport and the protection of.clean athletes. Lausanne: IOC. Press release, Dec. 10.

Kooinan, J., ed. (1993). Modem governance: New government - Society interactions. London: Sage.

Leftwich, A. (1994). Governance, the state and the politics of development. Development and Change, 25(2).

Lienhard, A., Kettinger, D. and Emery, Y. (2016). What management methods for justice? Le Temps.

Lipschutz, R.D. (2009). The constitution of imperium. London: Paradigm.

Maviomati, D. and Reeb, M. (2015). The code of the court of arbitration for sport: Commentary, cases and inaterials. The Hague: Kluwer Law International.

Pérez-Peña, R. (2003). Corporate governance. Paris: Discovery.

Perez-Peña, R. and Panja, T. (2018). 28 Russian athletes win appeals of doping bans. The New York Times.

Reeb, M., ed. (2004). Digest of CAS awards III 2001-2003. The Hague: Kluwer Law International.

Reinholz, F. (2019). Latest developments in the Pechstein case. 15 March. ISLA website. Available at: www. islasportlawyer.con//latest-developments-pechstein-case-ruling-european-court-human-rights/.

Rhodes, R.A.W. (1996). The new governance: Governing without government. Political Studies, 44(4)

Rosenau, J.N. and Czempiel, E-O., eds. (1992). Govemance without government: Order and change in world politics. Cambridge: Cambridge University Press.

Sternheimer, W. (2016). Introduction to the Court of Arbitration for Sport (CAS) and its procedures, presentation in Geneva.

Tribunal Fédéral. (2012). Francelino da Silva Matuzalem/FIFA: Statutory punishment contrary to public order.

UN. (2003). Convention against comption, Oct. New York: United Nations Organization.

UNESCO. (2005). International convention against doping in sport, Oct. Paris: United Nations Education, Science and Culture Organization.

Vaitiekunas, A. (2014). The court of arbitration for sport: Lau-making and the question of independence. Bern: Stämptli.

Wenn, S., Barney, R. and Martyn, S. (2011). Tarnished rings: The International Olympic Committee and the Salt Lake City bid scandal. Syracuse: Syracuse University Press. 


\section{Routledge Handbook of the Olympic and Paralympic Games}

Edited by Dikaia Chatziefstathiou, Editor-in-Chief, and Borja García and Benoit Séguin 